\title{
Building Relationship through International Office for Organization Competitiveness in Higher Educations
}

\author{
Iis Mariam ${ }^{1}$, Endah Wartiningsih ${ }^{2}$, Nining Latianingsih ${ }^{3}$ \\ \{iis.mariam@yahoo.com ${ }^{1}$, endah.wartiningsih@gmail.com ${ }^{2}$, nilaahen@yahoo.co.id ${ }^{3}$ \} \\ Politeknik Negeri Jakarta, Indonesia ${ }^{1,2,3}$
}

\begin{abstract}
In this era of disruption, changes in information technology have an impact not only on human resources but also on organizations. In building organizations, good relationships and networking with external parties have become a necessity for organizations to be able to compete and grow as strong organizations. This study discusses: (a) how is the role and function of an international office in building an organization?, (b) what strategies are doing for international offices to improve organizational competitiveness? This research was conducted in four Polytechnic, such as: State Polytechnic of Jakarta, State Electronics Polytechnic of Surabaya, State Polytechnic of Semarang and State Polytechnic of Bali. The research method uses qualitative, and data collection techniques using observation, study documentation and interviews. The results showed that the role and function of international office contributed to the relationship between Polytechnics and other foreign universities or colleges, students can participate in a student exchange programme, helped the lecturer continuing study for the master's or doctoral degree, partnership and cooperation relations for doing research. The strategy carried out by international office through SWOT analysis is to proactively provide information on Polytechnic partnerships with foreign universities, improving the positive image and accreditation of institutions.
\end{abstract}

Keywords: international office, competitiveness, polytechnic

\section{Introduction}

In the current era of disruption, the most change is the speed of information technology that affects not only companies, business organizations, government agencies including organizations in educational institutions like Polytechnics. The speed of accessing information is important in supporting the learning process not only by lecturers but also students. International Office is one of the units that support organizations at the Polytechnic have a function to develop its institutions in networking and collaborate with universities, government and industry. The role and function of the international office at Polytechnic can support "tridharma" such as: teaching, research, and community service for organizational competitiveness. In an organization, the strategies are

potential requirements that require top management decisions and large amounts of corporate resources [1]. The strategy in a learning organization is how it grows and has the competitiveness to win the competition [2]. There are three perspectives in winning the competition, such as: (a) the macro is related to the internal and external balance of the state and focuses on real exchange rate management, (b) business strategy relating to competition 
between firms and countries that have different roles and limited public policies, and (c) technologies and innovations that emphasize innovation and learning that produce value and high competitiveness [3] [4].

\section{Methodology}

\subsection{Research Methodology}

The research methodology used in this research is qualitative research using soft systems methodology (SSM) and descriptive qualitative. The research method based on the philosophy of postpositivism is used to examine the conditions of the researcher as an instrument of key sampling. The data source is purposive and snowball, collection techniques by triangulation (combined, inductive data analysis and qualitative research emphasize the significance of generalization [5] [6]. The SSM references to the seven principles, such as: (1) the problem situation is considered, (2) problem situation expressed, (3) definition of relevant purposeful activity systems, (4) conceptual models of named systems in the root definition, (5) comparison of models and real words, (6) changes: systematically desirable culturally feasible, (7) action to improve the problem [7] [5].

\subsection{Techniques of Data Collection}

Data collection techniques did through the study of documentation, informal discussion, participative observation and interviews with Head of international office, Assistant Director for academic and lecturer as the owner issue. The data has been grouped to associate with one another and interpreted by using SSM and also CATWOE approach (Clients, Actors, Transformation, Weltanschauung or worldview, Owners and Environment) in analyzing relationship building through the international office for organization competitiveness in polytechnic.

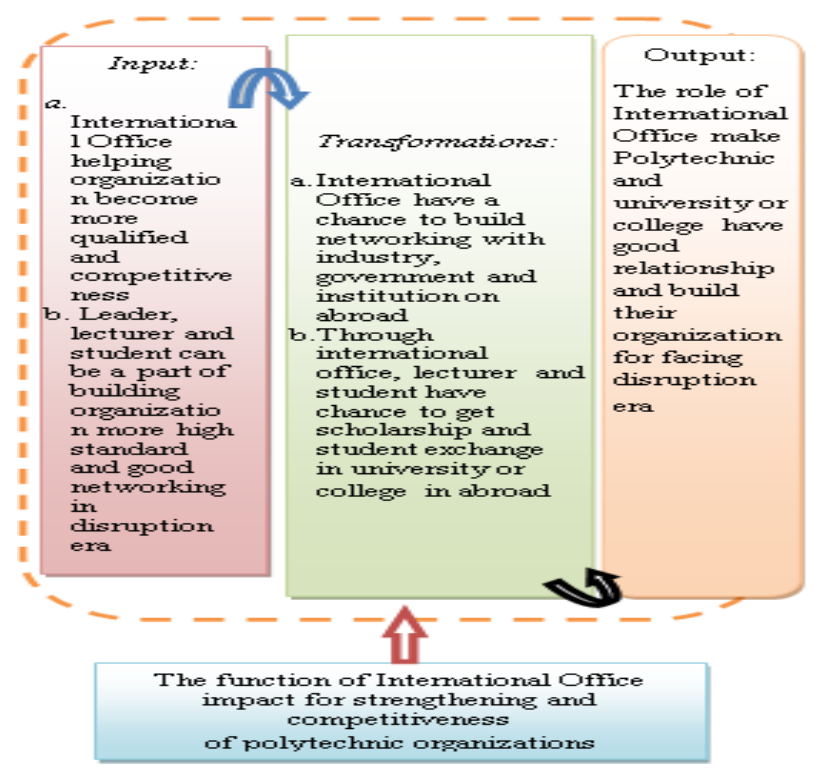

Figure 1. The Funtcion of International Office in Polytechnic Organization (Source: data processed, 2018) 


\section{Results and Discussion}

This study discusses how international office influences the activities of the organization with good capability and network. Based on Law No.12 of 2012 describes the system of use for Higer of Education and revitalization in polytechnic [8] [9] resulting in higher polytechnic graduate competition to be able to work in a company. The involvement of the government, associations and institutions in the education process including the pattern of cooperation with foreign higher education requires the existence of an international office that takes care of how to build good cooperation and relations between institutions abroad. The involvement of international offices in the student exchange and leading to Master and Doctoral lecturers program creates polytechnic organizations competing and applying the concepts of collaborative knowledge creation [3] [4] [6]. The following is a picture that explains the position of international offices in organizations at higher of education, especially Polytechnics

Table 1. Root Definition (RD) for the role of International Office in Polytechnic

\begin{tabular}{|c|l|l|}
\hline $\begin{array}{c}\text { ROOT } \\
\text { DEFINITION }\end{array}$ & \multicolumn{1}{|c|}{ PROCESS } & \multicolumn{1}{|c|}{ SYSTEM } \\
\hline \multirow{2}{*}{ RD } & $\begin{array}{l}\text { International Office policy } \\
\text { formulation within a form of } \\
\text { collaboration cooperation } \\
\text { and partnership polytechnic } \\
\text { with industry, companies, } \\
\text { governments, Associations } \\
\text { and other institutions. }\end{array}$ & $\begin{array}{l}\text { The system is owned and operated by polytechnics } \\
\text { in the framework of policy formulation (P) } \\
\text { through the improvement of interaction, } \\
\text { collaboration, communication and cooperation } \\
\text { network (Q) through the international office on } \\
\text { policy formulation process to improve the } \\
\text { competitiveness of the polytechnic organization. }\end{array}$ \\
\hline
\end{tabular}

Source: data processed, 2018

Table 2. CATWOE and 3E

\begin{tabular}{|l|l|}
\hline Customers & $\begin{array}{l}\text { Director, Assistant to Director for Academic Affairs, Assistant to Director for } \\
\text { Field of Cooperation and Industry, lecturer, government, professional association, } \\
\text { and industry. }\end{array}$ \\
\hline Actors & $\begin{array}{l}\text { Director, Assistant to Director for Academic, Assistant to Director for } \\
\text { Cooperation and Industry, lecturer, Head of International Office, Head of } \\
\text { Research and Community Service }\end{array}$ \\
\hline Transformation & $\begin{array}{l}\text { Information assymetry between educational providers with International office } \\
\text { based on esternalixing anda sharing process. }\end{array}$ \\
\hline Weltanschauung & $\begin{array}{l}\text { Submission of information between delivery is important to be implemented to } \\
\text { produce strategies for strengthening the dynamic capabilities of the organization } \\
\text { for international office regulation }\end{array}$ \\
\hline Owner & $\begin{array}{l}\text { Director, Assistant to Director for Academic ,lecturer, and Head of the } \\
\text { international office }\end{array}$ \\
\hline Environment & $\begin{array}{l}\text { Budgeting and time for running these programs based on policy from the } \\
\text { government are limited }\end{array}$ \\
\hline E-Eficasy & $\begin{array}{l}\text { The existence of externalizing and sharing to overcome the challenge of } \\
\text { information asymmetry in institutional cooperation network trough international } \\
\text { office }\end{array}$ \\
\hline E-Eficiency & Optimizing available resources, time and policy from organizations \\
\hline E-Efective & $\begin{array}{l}\text { The achievement of institutional cooperation network with external parties } \\
\text { Polytechnic trough the role of international office }\end{array}$ \\
\hline
\end{tabular}

Source: data processed, 2018 
Table 3 The Role and Strategic of International Office in Polytechnic

\begin{tabular}{|c|c|c|}
\hline NO & INSTITUTION & STRATEGIC FOR ROLE OF INTERNATIONAL OFFICE \\
\hline 1 & $\begin{array}{l}\text { State Polytechnic } \\
\text { of Jakarta (PNJ) }\end{array}$ & $\begin{array}{l}\text { a. Collaboration with another instituion and colleges in abroad (MSU-Malaysia, } \\
\text { A-e University Malaysia) and NPIC (Cambodia) } \\
\text { b. Have a program for student exchange (Taiwan) } \\
\text { c. Collaboration with Polytechnic of Kinabalu for joint seminar and community } \\
\text { services } \\
\text { d. Involve in international office forum in Indonesia } \\
\text { e. Support the leader of PNJ to make MOU with government and colleges or } \\
\text { university (MSU-Malaysia, India, Taiwan, Korea) } \\
\text { f. Dharmasiswa program from HGDE-Indonesia (Ghana, Taiwan, Japan, } \\
\text { Cambodia, Malaysia, and Turkey) } \\
\text { g. Teaching culture and Indonesian language for Dharmasiswa student } \\
\text { h. Create the strategy for improving international office fac ing disruption era } \\
\text { and competitiveness. }\end{array}$ \\
\hline 2 & $\begin{array}{l}\text { State Polytechnic } \\
\text { Electronica of } \\
\text { Surabaya } \\
\text { (PENS): PICO }\end{array}$ & $\begin{array}{l}\text { a. Have a program for student exchange (Taiwan, Japan) } \\
\text { b. Prepare a guide book orientation program for student exchange to come to } \\
\text { PENS } \\
\text { c. Scholarship for Master degree programme (Philipines and Keyo University in } \\
\text { Japan), P.hD programme (Okayama University and Toyashi University of } \\
\text { Technology) } \\
\text { e. Collaboration with SEAMO, Taiwan and South Korea for student exchange } \\
\text { f. Involve in international office forum in Indonesia } \\
\text { g. Support the leader of PENS to make MOU with government and colleges or } \\
\text { university in abroad } \\
\text { h. For promoting the programme: www.pico.pens.ac.id } \\
\text { i. Joint research with Keyo University-Japan, NTU Singapore, California } \\
\text { Polytechnic for a newrable energy. }\end{array}$ \\
\hline 3 & $\begin{array}{l}\text { State Polytechnic } \\
\text { of Semarang } \\
\text { (POLINES) }\end{array}$ & $\begin{array}{l}\text { a. Have a programme for student exchange (Taiwan and Belgia) } \\
\text { b. Have a programme of Dharmasiswa } \\
\text { b. Involve in international office forum in Indonesia } \\
\text { c. Support the leader of POLINES to make MOU with government and colleges } \\
\text { or university abroad. }\end{array}$ \\
\hline 4 & $\begin{array}{c}\text { State Polytechnic } \\
\text { of Bali (PNB): } \\
\text { UKHPI }\end{array}$ & $\begin{array}{l}\text { a. UKHPI Have a program for student exchange (Taiwan and South of Korea) } \\
\text { b. Involve in international office forum in Indonesia } \\
\text { c. Support the leader of PNJ to make MOU with government and colleges or } \\
\text { university (MSU-Malaysia, India, Taiwan, South of Korea) } \\
\text { f. Lecturer exchange for Taiwan } \\
\text { g. Credit transfers were carried out in } 2017 \text { with } 3 \text { students studying in France (6 } \\
\text { months MOU) and } 2 \text { students studying in Taiwan for one month. }\end{array}$ \\
\hline
\end{tabular}

\section{Conclusions}

The International Office has the duties and functions as a mediator and creator in the organizational development process at the Polytechnic. Building relations and communication with institutions, colleges and government abroad have an impact on improving the quality of students through student exchange programs, opportunity scholarships for lecturers study for the Master degree program and Doctoral degree programs. The polytechnic policy in supporting the role of international office running the programs with enough budget and the potential and qualified human resources, so that why polytechnics are able to compete and wiining competion in the disruption era. 


\section{Acknowledgement}

I would like to say thanks to State Polytechnic of Jakarta whose already given a chance and funding for me and made this research finished on schedule sucessfully.

\section{References}

[1] David, Fred R. Manajemen Strategis Konsep. Terjemahan oleh Dono Sunardi dari Strategic Management. Jakarta: Salemba Empat (2011).

[2] Wignaraja, Ganeshan. Competitiveness strategy in developing countries. A Manual for policy analysis, Routledge Studies in Developing economics (2005).

[3] Du Chatenier, Elise, Jos.A.A.M. Verstegen, Harm J.A. Biemans, Martin Mulder dan Onno Omta. The Challenge of Collaborative Knowledge Creation in Open Innovation Teams, SAGE, October (2009).

[4] Jakubik, Maria. Experiencing a Collaborative Knowledge Creation Process. The Learning Organization, Vol. 15. No. 1, pp: 5-25, (2008).

[5] Checkland, Peter dan John Poulter. Learning for Action. John Wiley \& Son. New York. USA (2006).

[6] Kezar, A. Redesigning for collaboration within higher education institutions: An exploration into the developmental process. Research in Higher Education,47(7), 831-860, (2005).

[7] Checkland, Peter. System Thinking, Systems Practice. John Wiley \& Son. New York. USA (2011).

[8] Salisbury, DA. Framework for Collaborative Knowledge Creation, Knowledge Management Research and Practice. No. 6 (2008).

[9] Lee, Young S and Matthew A.Schottendfeld. Collaborative knowledge creation in the higher education academic library. Journal of Learning Spaces, ISSN: 21586195, Vol.3, No.1, (2014). 